\title{
NO BOSQUE FICCIONAL DE TRISTRAM SHANDY: LEITOR E NARRADOR NAS ENTRELINHAS
}

\author{
Aline Candido Trigo ${ }^{1^{*}}$ \\ ${ }^{1}$ Universidade Estadual Paulista "Júlio de Mesquita Filho", Assis, SP, Brasil \\ Luciana Brito ${ }^{2 * x}$ \\ ${ }^{2}$ Universidade Estadual do Norte do Paraná, Jacarezinho, PR, Brasil
}

\begin{abstract}
Resumo
Este trabalho analisa as figurações do leitor em Tristram Shandy, de Laurence Sterne, a partir das ideias de Umberto Eco, Gerard Genette e Maurice Blanchot, com foco na relação entre narrador e leitor e o efeito estético decorrente das técnicas formais. Frente a um narrador-autor-personagem autoconsciente, os jogos com os limites do real e do imaginário são recorrentes e desafiam os mais variados tipos de leitores ainda na contemporaneidade. Ao refletir sobre o ato da leitura, o texto encena as ações de variados tipos de leitores através do discurso do narrador. Considerada por Virginia Woolf a precursora do romance moderno, a obra recebe pontos de vista distintos no que tange à interpretação de sua forma, conforme será discutido aqui, ao ponto de ser, por vezes, melhor compreendida pelos escritores shandianos que the seguiram o influxo de ressignificação da mimesis e da forma literária.

Palavras-chave: Tristram Shandy; Narrador; Leitor; Narratário

INTO THE FICTIONAL WOODS OF TRISTRAM SHANDY: READER AND NARRATOR BETWEEN THE LINES
\end{abstract}

\section{Abstract}

This work analyzes the figurations of the reader in Tristram Shandy, by Laurence Sterne, based on the ideas of Umberto Eco, Gerard Genette, and Maurice Blanchot, which focus on the relationship between narrator and reader, and the aesthetic effect resulting from formal techniques. In face of a self-conscious narrator-author-character, the play with the limits of

\footnotetext{
Doutoranda em Letras pela Universidade Estadual Paulista "Júlio de Mesquita Filho" (UNESP), com bolsa CAPES. Possui mestrado em Letras pela Universidade Estadual de Londrina (UEL), onde desenvolveu pesquisa sobre o romance Tristram Shandy também com financiamento da CAPES, e graduação em Letras PortuguêsInglês pela Universidade Estadual do Norte do Paraná (UENP). E-mail: alinee.three@gmail.com. ORCID ID 0000-0002-5061-6044.

** Possui graduação em Letras pela Universidade Estadual Paulista Júlio de Mesquita Filho (2000), mestrado em Letras pela Universidade Estadual Paulista Júlio de Mesquita Filho (2003) e doutorado pela Universidade Estadual Paulista Júlio de Mesquita Filho (2008). Atualmente é docente do Centro de Letras, Comunicação e Artes da UENP e coordenadora de dois Grupos de Pesquisa com registro no CNPQ. Também atua como docente do Programa de Pós-Graduação em Letras da UEL. E-mail: lbrito@uenp.edu.br. ORCID: 0000-00033378-7279.
} 
reality and imagination are frequent, and it challenges the most diverse kinds of readers even in contemporaneity. Reflecting about the act of reading, the text performs the actions of multiple kinds of readers through the narrator's discourse. Considered by Virginia Woolf the forerunner of the modern novel, Sterne's work causes discrepancy regarding the interpretation of its form as it will be discussed here, by the point of being sometimes better comprehended by shandean writers that took the novel as a reference, re-signifying the mimesis and the literary form.

Keywords: Tristram Shandy; Narrator; Reader; Narratee 
Estudante e caçador. O texto é uma floresta na qual o leitor é o caçador. Rumores na floresta: a ideia - a presa arisca; a citação - uma peça do quadro. (Nem todo leitor consegue encontrar a ideia.)

(Walter Benjamin - Passagens - m, p. 841)

Resultado de intensas transformações sociais do indivíduo, o romance enquanto gênero começa a ser pensado no século XVIII como forma de expressão do indivíduo, ao mesmo tempo representando e moldando valores e interesses sociais. O cenário iluminista efervesceu a mente de diversos escritores e escritoras que arriscaram as penas tanto em experimentar novas formas de representação da subjetividade, como novas visões teóricas sobre a narrativa que dessem conta de abarcar esse gênero híbrido e amorfo. Disso resulta a Querela entre os Antigos (os que defendiam os gêneros literários clássicos da Antiguidade) e os Modernos (os que defendiam o romance e os novos artistas), conflito iniciado na França em fins do século XVII e estendido à Inglaterra, denominado, no século XVIII, como Batalha dos Livros. Em contraste ao espírito de avanços nas diversas áreas, nas artes, o Século das Luzes retomava valores e princípios aristotélicos, muitas vezes privilegiando o ético sobre o estético. Sendo assim, "tomar armas contra o romance durante o primeiro ano das Guerras Culturais foi também um perfeito, embora indireto, ataque à doutrina Moderna de que a originalidade deveria ser valorizada acima da tradição." (DEJEAN, 2005, p. 88).

Nesse contexto, surge na Inglaterra uma obra que seria reprovada pelos Antigos e que, a cada crítica publicada sobre seus volumes, tratava de satirizar e ousar ainda mais na experimentação artística: A vida e as opiniões do cavalheiro Tristram Shandy (1760-1767), o primeiro romance de Laurence Sterne. Autoconsciente, apresenta reflexões sobre os procedimentos narrativos e os limites dos gêneros literários, bem como questionamentos aos ensejos de realismo por romancistas do período. Apesar do grandioso sucesso, a cada publicação dos volumes, tendo sido os dois primeiros muito bem recebido pela crítica especializada, Sterne fazia dos comentários mote para a autoconsciência de seu narrador, ironizando o saber letrado. Com isso, a partir do terceiro volume, os críticos passam a reclamar publicamente das ofensas e a atestar que se tratava de uma obra extravagante, aleatória, nonsense, desprovida de caráter artístico, como é o caso da resenha publicada na revista The Critical Review, volume XI, de abril de 1761, que diz: "uma efusão desconexa de sentimentos e comentários, expressos indiscriminadamente à proporção que surgiram em sua imaginação" (VASCONCELOS, 2007, p. 532).

O narrador-autor perpassa livremente por influências e formas que traz para o texto através de digressões, colagens e experimentos gráficos, configurando sua busca pelo fazer literário e autobiográfico. Desse modo, conforme análises de Melvyn New (1992), percebe-se que Sterne encena diversas formas de escrita e de leitura que fazem flutuar as certezas e determinações, não como uma entrega ao caos, mas como indicação de que o ser humano persegue uma busca constante por narrar a verdade, desconsiderando as infindáveis variações desta. A liberdade e fragmentação da narrativa fizeram com que muitos críticos inter- 
pretassem a obra como aleatória e caótica. Wayne Booth (1952, p. 163, tradução nossa) retoma essa trajetória de recepção crítica e atesta que Sterne "dependia de um plano razoavelmente elaborado. Leitores modernos, em suma, tendem a ver maestria onde leitores anteriores viram apenas capricho". Tristram Shandy convoca a uma leitura permeada de dúvidas quanto a uma possível continuidade da obra, como se o nono volume não fosse de fato o fim. Para o crítico shandiano, no entanto, há na obra indícios consistentes de uma circularidade poética, visto que no último capítulo, com os temas trazidos pela personagem Obadiah sobre sexualidade, gestação, fertilidade, esterilidade e relações sexuais, completa-se o ciclo de temas que foram largamente abordados desde o início (BOOTH, 1950). Apesar da convergência entre as ideias transversais e o tema principal, para o leitor, a obra configura-se como sendo um texto de contingências. Tristram Shandy, como observa Virginia Woolf (2007, s./p.), é "um mundo em que qualquer coisa pode acontecer. Dificilmente sabemos que gracejo, que zombaria, que lampejo de poesia não estará à espreita de repente através da brecha aberta por esta pena surpreendente e ágil [...]”.

Tristram, narrador que se declara autor da obra, está em busca da melhor e mais fidedigna maneira de escrever um romance autobiográfico, e então decide começar a narrativa pelo verdadeiro início: o momento em que foi gerado, o qual, segundo ele, influenciou diretamente o seu caráter e seu destino. No entanto, sua proclamada intenção de escrever um romance que de fato lhe narre a vida e as opiniões não é tão objetiva e simples quanto parece, e sua relação com o leitor não será tão amigável quanto promete logo nas primeiras páginas: "à medida que me for o senhor avançando no que a mim respeita, o ligeiro conhecimento que ora desponta entre nós se converterá em amizade" (STERNE, 1984, p. 53).

$\mathrm{Na}$ obra, o ato da leitura é uma temática para o enredo, uma vez que Walter Shandy - pai de Tristram - é um leitor voraz, que vive a discutir temas excêntricos que lê em livros também denominados estranhos pelo narrador; Toby - irmão de Walter - é um leitor obcecado pelo assunto de projéteis de guerra; Trim - criado de Toby - adora ler qualquer gênero em voz alta, para uma audiência; o leitor-personagem e a leitora-personagem, que dialogam com o narrador, são afeiçoados a leituras com enredo linear e verossímil; e Tristram é leitor dos mais variados temas e gêneros, os quais copia na íntegra, inventa, parodia, satiriza, intertextualiza e menciona a título de exemplo. Sempre que a história ou anedota de alguma das personagens é narrada, a leitura aparece como ação. As frequentes conversas que Walter tem com Toby e com o parteiro, Dr. Slop, por diversas vezes, resultam em alguma leitura de trechos de obras às quais Walter faz referência, e que Tristram transcreve nas páginas do romance para nos colocar a par da cena. $\mathrm{O}$ acervo de leitura de que dispunha o pai do protagonista era tamanho que este sente a necessidade de escrever uma enciclopédia para seu filho como forma de transmitir todo o seu conhecimento e sua peculiar visão de mundo. Intitulada Tristrapaedia, a obra é confeccionada por Walter durante três anos, até que este percebe que jamais conseguiria dar conta desta tarefa efetivamente. Trata-se, aqui, de uma sátira ao sistema de educação enciclopédica do Iluminismo. 
O livro também tematiza a sua própria recepção, despertando o leitor para o caráter ficcional da obra. É o caso da menção que o narrador faz ao receio das senhoras burguesas em relação à malícia da obra e do público leitor, visto que, após o sucesso dos dois primeiros volumes, recusavam-se a adentrar relojoarias para não ouvirem comentários maldosos devido à passagem de Tristram Shandy que discorre sobre o ato de concepção do protagonista (STERNE, 1984, p. 47-48). Além disso, ironiza a conhecida expectativa que pairava sobre os senhores aristocratas em receber dedicatórias nos livros populares, para as quais se dispunham a pagar quantia em dinheiro. Colocando em evidência o jogo de poder que recai sobre a relação autor, narrador e leitor, Tristram reposiciona o lugar da dedicatória e a coloca à venda a qualquer leitor que dela fizer questão, anunciando a venda do que chama "Dedicatória-Virgem" endereçada à "Milorde" (STERNE, 1984, p. 57). Ao alterar a ordem do livro, apaga por completo o prestígio de tal honraria, pois a dedicatória se encontra ao fim do capítulo oito, do volume I.

Tristram Shandy deixa traços de uma consciência da realidade leitora do período, aspecto que serviu de base para a formação do gênero romance em si, uma vez que diversos escritores de então, conscientes das expectativas de autenticidade de uma obra, buscavam supri-las em prol de valores aristotélicos, como verossimilhança e condenação de vícios. O leitor setecentista buscava a coerência subjetiva das personagens, anseio que Sterne satiriza e afronta, rompendo com as formalidades e com os temas tradicionais. Frente a seus pares, conforme aponta Luiz Costa Lima (2009, p. 328), "[...] Sterne destaca-se pelo oposto de qualquer continuidade. É sua singularidade que o torna objeto das críticas ferozes de seus contemporâneos".

Sterne fez da recepção crítica impulso para a liberdade ficcional. Ao traçar um jogo entre realidade e ficção, faz com que o leitor precise ser tão digressivo em sua imaginação, quanto é digressiva a própria narrativa. Pelo discurso de seu narrador, deixa traços de que concebia a obra como uma arte aberta a múltiplas interpretações, e exprime isso numa experimentação de diversas formas de vazios na narrativa. Hoje, essa visão é consenso teórico: toda obra de arte possui uma abertura, em maior ou menor grau, que permitirá ao leitor “[...] uma multiplicidade de significados que ele deverá descobrir; inclusive, conforme seu estado de ânimo, ele escolherá a chave de leitura que julga exemplar, e usará a obra na significação desejada [...]" (ECO, 2001, p. 43). Em Tristram Shandy, essa noção de liberdade do leitor desponta em diversas partes, principalmente quando há alguma passagem de referências sexuais. O narrador frequentemente ressalta, em tom brincalhão, que é unicamente do leitor uma significação maliciosa das passagens. Por considerar que a arte de escrever é "apenas um outro nome para a conversação", convida o leitor para ajudá-lo a compor a obra:

Assim como ninguém que saiba de que maneira conduzir-se em boa companhia se arriscaria a dizer tudo,_- assim também nenhum autor que compreenda as justas fronteiras do decoro e da boa educação presumirá conhecer tudo. $\mathrm{O}$ respeito mais verdadeiro que podeis mostrar pelo en- 
tendimento do leitor será dividir amigavelmente a tarefa com ele, deixando-o imaginar, por sua vez, tanto quanto imaginais vós mesmo.

[...] a imaginação do leitor deve agora continuar por sua conta durante algum tempo. (STERNE, 1984, p. 136).

Tristram sabe, porém, que há leitores que não gostam de digressões, pois isso dificulta a imersão na história. Do mesmo modo, há também leitores que o condenam por não usar somente palavras na narrativa, e por não respeitar a regra clássica das três unidades - tempo, lugar e ação. Por vezes, a referência dos tipos de leitores se dá por meio de pronomes e expressões do tipo "senhor", "senhora", "caro leitor", "inculto leitor". Tristram demonstra conhecer muito bem o seu "amigo leitor", com quem compartilha suas experiências narrativas. Por tratar-se de uma inserção de figuras e acontecimentos em um espaço ficcional (diegético), ainda que esse leitor ali representado corresponda aos leitores do período, temos aí um recurso denominado narratário: um personagem que desempenha o papel de leitor da obra. Esse leitor se torna, então, mais próximo e livre do que o leitor real da obra, com características que lhe são impostas pelo texto. Para Hutcheon (1985, p. 115), em Tristram Shandy “[...] o narrador pode, com efeito, manejar verbalmente o seu leitor, mas parece continuar a haver uma suposição tácita de que o leitor e narrador partilham um conjunto de valores e back-ground educacional (de forma que não há necessidade de traduzir línguas estrangeiras, por exemplo)”.

Ao satirizar os costumes de leitores do período, pensou-se que o autor buscava moldar a leitura por meio de coordenadas narrativas para que o leitor pudesse melhor compreender a obra. Isso porque, para alguns críticos e teóricos literários, o recurso do narratário desempenha a função de captar a atenção do leitor empírico - o leitor real - e orientar-lhe quanto ao modo de ler. Em ensaio sobre o narratário em Fielding e Sterne, Gama-Khalil (2013) considera que tal recurso, neste último, representa o leitor iluminista, que espera uma narrativa ordenada. Para demonstrar essa consciência do autor, apresenta passagens de Tristram Shandy em que o narrador dialoga com esse leitor, afirmando que, com isso:

A rede de contrariedades, em vez de afastar os leitores, acaba por aproximá -los. A provocação é uma forte arma da sedução. Desapontando o leitor, o narrador, consegue mantê-lo atento àquelas memórias narradas de forma tão irregular. O desapontamento, a contrariedade e a surpresa instigam o prosseguimento da leitura. (GAMA-KHALIL, 2013, p. 148-9).

Considera, portanto, que a criação de um personagem leitor é uma ideação do autor para ironizar e dialogar com seus leitores reais, ao que entende como representação de "vozes da recepção". Em sua perspectiva de análise, "[...] o narratário, enquanto presença fisicamente percebida na narrativa, funciona como um espaço onde o leitor que lê a narrativa pode instalar-se" (GAMA-KHALIL, 2013, p. 152). Assim, o narratário seria uma entidade com a qual o leitor real pode se identificar, pois é uma representação de leitor-modelo com efeito educativo. Essa noção é abordada também por Lajolo e Zilberman (1998, p. 17) em pesquisa que analisa uma tradição de leitor ficcionalizado na literatura brasileira, que confi- 
gura um recurso para controle e instrução de um leitor ainda em formação. As autoras encontram representação para esse termo em obras que utilizam o recurso como "projeção do desejo do escritor", tratando-se, portanto, de um "irmão e semelhante do leitor empírico" (LAJOLO; ZILBERMAN, 1998, p. 17).

Neste trabalho, porém, nos distanciaremos de tais perspectivas de narratário. O crítico Wayne Booth, que investiga o histórico de narradores intrusos anteriores a Tristram Shandy, atesta que os predecessores de Sterne utilizavam o recurso de comentários do narrador em diálogo com o leitor para conduzir as atitudes deste. Assim, Sterne se distancia dessa visão moralista de controle do leitor, mantendo "debates entre narrador e 'leitores' de diferentes tipos" confeccionando "um produto literário" e não um mero artifício narrativo (BOOTH, 1950, p. 69, tradução nossa). O diálogo com o leitor, portanto, configura uma experiência estética que se concretiza frente aos desenhos e outras liberdades gráficas utilizadas para representar ideias que as palavras não abarcam, trazendo aí um silêncio que esfacela a ideia de que o autor considera o seu leitor tão incapaz a ponto de precisar "conduzi-lo pelas mãos", ainda que, por vezes, apareça um narratário assim. O leitor ideal e os leitores empíricos são convidados a ultrapassar os limites da linguagem em uma experiência com o simbólico.

Para Blanchot (2018, p. 128), o símbolo é experiência que "deve ser vivida", configurando uma "experiência simbólica" e, portanto, só haverá símbolo para e a partir do leitor: "é o leitor que, diante da narrativa, experimenta um poder de afirmação que parece transbordar infinitamente a esfera limitada em que esse poder se exerce". Um leitor shandiano só poderá apreciar a obra se for tão livre quanto seu autor, visto que o esvaziamento de palavras exige também uma liberdade na interpretação que não se contente em resumir em palavras aquilo que escapa ao autor e transborda as linhas tradicionais, configurando um projeto gráfico que também não se limita aos padrões literários. Para Fanning (1998, p. 442, tradução nossa), que identifica a organização espacial da obra como metáfora da dificuldade de comunicação entre as personagens, "é a ausência de excesso de tinta que representa a performance. Em outras palavras, é o espaço desocupado na página que produz muitos dos efeitos de Tristram Shandy".

Diante disso, utilizaremos a perspectiva de Umberto Eco acerca de leitor-empírico e leitor-modelo, e de Gérard Genette acerca do narratário, para lançar um olhar sobre a relação entre narrador-autor e leitores. Tais escritos nos conduzem à ideia de que, em Tristram Shandy, este aspecto da ficcionalidade é transgressor na medida em que mescla realidade e ficção, representando diferentes modelos de leitores não enquanto projeto educativo do autor, mas sim de um narrador/escritor que quer explorar os limites da narrativa, e que ao ficcionalizar formas de leitura, eleva a reflexão sobre a importância do receptor para a existência da obra de arte.

Entidades ficcionais, os narratários não possuem compromisso com a realidade e nem podem ser usados como modelo para a leitura. Pela definição de Genette (1930, p. 258), o narratário, assim como o narrador, "é um dos elementos da situação narrativa, e coloca-se, necessariamente, no mesmo nível diegético; quer dizer que não se confunde mais, a priori, com o leitor (mesmo virtual ${ }^{1}$ ) de 
que o narrador com o autor, pelo menos não necessariamente". As afirmações de Tristram sobre seus leitores, ainda que por vezes ele se refira a leitores reais (como os críticos de revistas que avaliavam os volumes da obra), podem ser correspondentes, ou não, à voz do autor Sterne.

O termo leitor-implícito, adotado por Genette, corresponde a uma entidade textual que atualiza o sentido do texto e acompanha o discurso do narrador quando este textualiza um leitor. Por se tratar de um conceito bastante semelhante ao de leitor-modelo de Eco, cabe destacar que Eco define que, para Iser "[...] o 'conceito de leitor implícito é, portanto, uma estrutura textual prevendo a presença de um receptor' [...] Para Iser 'o papel do leitor não é idêntico ao do leitor fictício retratado no texto. Este último é apenas um componente do papel do leitor"' (ECO, 1994, p. 22). Seja analisando o leitor-modelo, leitor-implícito ou narratário, tanto Genette quanto Eco e Iser são claros ao determinar que nenhum destes é correspondente ao leitor real, e sequer representam as escolhas deste leitor real dentro do bosque narrativo.

Para Eco (1994, p. 9), "todo texto é uma máquina preguiçosa pedindo ao leitor que faça uma parte de seu trabalho". Diante disso, é possível afirmar que todo autor tem em mente um leitor-modelo, aquele que será capaz de compreender as nuances da obra, sendo, portanto, "um tipo ideal que o texto não só prevê como colaborador, mas ainda procura criar" (ECO, 1994, p. 15). Porém, esse leitormodelo não será necessariamente guiado pelas demandas de um narrador (ente ficcional), e sim pelas escolhas lexicais e estruturais que formam a obra, exposto, portanto, pelo estilo do autor, que constitui a presença do autor-modelo, conforme entendido pelo teórico italiano.

Quando um narrador dá instruções diretas a um leitor ficcionalizado, visto que é personagem, este pode até seguir as orientações do narrador (através da imaginação do leitor empírico), mas os leitores reais - nós -, se o fizerem, encontrarão grandes entraves para a compreensão da obra. É o caso da relação que Sterne estabelece: no volume VI, ao narrar que seu tio Toby se apaixonou pela sensual viúva Wadman, Tristram dispõe ao leitor uma página inteira em branco para que este a desenhe conforme sua imaginação, de modo que, ao fazê-lo, o leitor não acuse Tristram de malícia, pois é uma criação que ele entrega ao leitor e, assim: "nem a Malícia há de escurecer nem a ignorância poderá deturpar" (STERNE, 1984, p. 460). Segue abaixo a referida passagem:

Para conceber a contento o que seja,-mandai buscar pena e tinta-eis papel em branco ao vosso dispor--Sentai-vos, senhor, e pintai-a como quiserdestão parecida quanto puderdes com a vossa amante-tão diferente de vossa esposa quanto a consciência vos permitir-para mim dá tudo na mesmacuidai tão-só de deleitar vossa fantasia. (STERNE, 1984, p. 458).

A presença do papel em branco proporciona ao leitor um percurso imaginário que o autor não sonha em controlar. O sentido será estabelecido através do significado que cada um particularmente atribui tanto à ação do narrador, de deixar a folha em branco, quanto à liberdade proposta, de imaginar a person- 
agem. O leitor ideal é aquele que desconfia do texto escrito, lendo, portanto, as entrelinhas, e o "leitor real é aquele que compreende que o segredo de um texto é o seu vazio" (ECO, 2005, p. 46). É por isso que o narratário, enquanto entidade ficcional convocada pela página em branco em Tristram Shandy, consiste em "uma testemunha da impossibilidade de perfeita comunicação na linguagem, o que pode ser o motivo pelo qual não se conheça nenhum leitor que tenha aderido ao desafio de Tristram em nenhuma cópia sobrevivente ${ }^{2 "}$ (DE VOODGE, 2009, p. 145, tradução nossa).

Em Tristram Shandy ocorre uma sobreposição de planos narrativos, num desdobrar de diversos acontecimentos simultâneos, como uma mise em abyme. Muitas das histórias narradas ocorreram durante o nascimento do narrador ${ }^{3}$, que congela o tempo e passeia por diferentes planos diegéticos, por vezes adentrando esse outro tempo e interagindo com as personagens: “-Meu querido tio Toby! Não entres na guarita com o cachimbo,-não se pode confiar num homem com tal coisa na mão em semelhante lugar" (STERNE, 1984, p. 446). Ocorre aí o que Rouanet (2007, p. 166) entende como "interferência recíproca do tempo da ação e do tempo narrado pelos personagens", numa tentativa de "produzir um futuro alternativo". Não se trata apenas de um narrador onisciente, mas de um diálogo com as formas dramáticas, quebrando a expectativa de narração, abrindo e fechando cortinas conforme a memória lhe apetece. É como se Tristram estivesse sentado a assistir, em outro plano diegético, à ação do passado de seus familiares em Shandy Hall, a qual nos convida a assistir ao lado dele": "Vamos agora adentrar um novo cenário de sucessos.-——- [...] Deixemos minha mãe [...] Deixemos, se possível, a mim mesmo.-Mas isso é impossível:-devo acompanhar-vos até o fim da obra” (STERNE, 1984, p. 435).

Sua presença é constante porque é por sua voz que o receptor sabe das histórias, e essa voz apresenta uma particular visão de mundo que influencia o recorte e a forma narrativa. Mas é também uma voz de escritor literário autoconsciente, que convoca o leitor a se fazer presente com suas próprias opiniões e sentimentos. O narrador percebe a escrita de memórias como uma encenação, e consciente das múltiplas e livres possibilidades de recepção, ironicamente orienta o narratário quando este pode parecer confuso, ou quando acha que ele não entenderá algum aspecto de seu discurso. Mas não é o caso, aqui, de observarmos se esse leitor ficcionalizado corresponde à noção de leitor que possui o autor (se é que seria possível tal análise). Interessa-nos notar que o autor, ao criar uma narrativa autorreflexiva, cria também uma representação dos limites da linguagem e da relação dialética dos discursos, visto que, na perspectiva de Mikhail Bakhtin (2006, p. 115):

[...] toda palavra comporta duas faces. Ela é determinada tanto pelo fato de que procede de alguém, como pelo fato de que se dirige para alguém. Ela constitui justamente o produto da interação do locutor e do ouvinte. Toda palavra serve de expressão a um em relação ao outro. Através da palavra, defino-me em relação ao outro, isto é, em última análise, em relação à coletividade. 
A perspectiva de Tristram é de que seu leitor possui opiniões e expectativas em relação ao que está a contar, e que a experiência de cada indivíduo influencia sua percepção de mundo. As obsessões das personagens nada mais são do que essa perfeita representação: Toby, por ter se ferido em uma batalha, agora compreende o mundo como alegoria daquele cenário, o que torna difícil sua relação com quem não é afeiçoado a assuntos bélicos; o narrador faz reflexões sobre a sua maneira de contar as histórias e de organizar o romance para que "ao mesmo tempo em que contento esse ouvido que o leitor se digna a prestar-me--não descontento o outro que ele guarda para si mesmo" (STERNE, 1984, p. 489). Nesse embalo de mostrar os entraves do processo de escrita do personagem/autor, Sterne dá voz direta ao narratário, que exclama: "Mas que história estranha, Tristram!" (STERNE, 1984, p. 495).

Como o narratário encontra-se no mesmo plano diegético que Tristram, pois escuta o narrador e também se faz ouvido, exclui-se completamente a possibilidade de todo leitor se identificar com tal personagem, e de pensarmos ser esse narrátário uma figuração do leitor real ou leitor-modelo:

[...] empreguemos algum meio honesto para tirá-la desde logo de nossas cabeças.

- Por favor, passai-me o gorro de bufão.-Receio que estejais sentada sobre ele, senhora-acha-se debaixo da almofada-vou pô-lo na cabeça.-

- Deus me valha! Nesta última meia hora ele não estava em vossa cabeça.

- Então, que fique ele por aí, com um

Trá-la-la dim-dem-dim

E um trá-lá-li dim-dem-d

E um tim-bum-tim-bum

Nhem - - dum - ss.

E agora, senhora, espero eu possamos aventurarmos a ir um pouco mais adiante. (STERNE, 1984, p. 496).

No excerto, Tristram se mostra no mesmo ambiente que sua leitora ${ }^{5}$, e o leitor-modelo pode inferir as ações desta a partir do discurso do narrador em destaque. Os narratários que dialogam com o narrador são leitores que se frustram diante da ruptura com as convenções narrativas. Por isso a metáfora do chapéu de bufão, que a leitora, além de não vestir, ainda senta sobre, esmagando toda a possibilidade de acompanhar as cabriolas do livre narrador. Por ser o bufão alguém dado a entreter e arrancar risos, o narrador brinca com uma musicalidade de palavras malucas ${ }^{6}$, mostrando uma interação que não é comum ao texto escrito, mas sim à oralidade.

Para Iser (2008), Tristram acredita que o leitor precisa ser preparado para o diálogo. Os recursos, que o narrador-autor afirma aplicar no romance, desautomatizam o olhar do leitor e ativam sua imaginação, fazendo com que sua presença seja constante na obra, criando um relacionamento dialógico entre as entidades que competem à autoria, à narrativa e à leitura, conforme análise abaixo: 
Porque ele [o leitor] deve ser atraído para um diálogo no qual o narrador, o autor e os personagens estão misturados, senão embaralhados. A participação do leitor, entretanto, deve ser de tal modo que ele possa ser impedido de remover a plurivocidade por meio de suas próprias projeções. O narrador tem se esforçado em produzir abertura em suas interrupções, e, portanto, é essencial que o leitor não seja autorizado a impor seus próprios padrões, fechando, assim, o que havia sido aberto. ${ }^{7}$ (ISER, 2008, p. 63, tradução nossa).

É assim um texto livre de determinações e de limitações quanto a qualquer saber. Ao escolher representar a morte com páginas pretas, ao dialogar com a pintura na inserção de páginas marmóreas, ao utilizar travessões de diferentes tamanhos e pontuações como substituição de palavras, bem como ao arrancar capítulos, o narrador-autor busca proporcionar ao ato da leitura um mergulho em consciência mais profunda e subjetiva. Para Nícea Nogueira (2004), tais ações são "violências literárias" que ameaçam o que a autora denomina de "leitor imaginário", e reafirmam a autoridade de um narrador monológico:

Parece-nos que ele está sempre dando ordens, ao seu público, para que ora pare, ora continue; para que releia as páginas anteriores; pule para frente, logo depois para trás; suspenda, temporariamente, o que foi dito e assim por diante. Consegue que o leitor fique à sua mercê e tenta impressioná-lo com sua erudição, presença de espírito e genialidade. Todo este processo é realizado de forma extremamente intencional, fazendo de Tristram um dos narradores auto-conscientes mais expressivos da literatura inglesa. (NOGUEIRA, 2004, p. 165).

No que tange à autoridade do narrador, que consegue capturar o ato da leitura sob sua tutela, nos distanciamos do pensamento da autora, uma vez que creditamos, a esse desvelamento do jogo ficcional, um aceno para a liberdade da qual usufrui o leitor. Ainda que, conforme vimos na análise de Iser, não seja possível retirar da obra conhecimentos fechados e limitadores, também é necessário que se apresente na leitura a subjetividade do próprio leitor, que ativará o sentido cada qual a sua maneira. Interessante notar, no excerto acima, que a autora considera a consciência acerca dos leitores como algo pertencente ao narrador, que o define como narrador autoconsciente. É por se tratar de um personagem escritor que justificamos voltar o olhar para sua concepção acerca da recepção dentro do âmbito ficcional.

Ao propor ao leitor uma participação ativa na produção do romance, ocorre o que Carlos Ceia (1999, p. 27) chama de "condição pós-moderna de embargamento da representação objetiva do real". Quebra-se um estado de contemplação ficcional e realoca-se o pacto ficcional em outro plano da diegese. Para o crítico, Sterne se utiliza da premissa de "disrupção de sentido", que consiste em fazer uso de colagens, imagens, cópias de outros textos, referências a outros textos e pessoas, de modo a guiar a compreensão do leitor "com o objetivo de ensinar que o sentido do texto nunca está completo, nem o leitor pode ambicionar a tê-lo nas suas mãos seguras" (CEIA, 1999, p. 25). Se o leitor-empírico possui conhecimen- 
to sobre aquilo que Sterne cita, por exemplo, a interpretação será conduzida por um caminho adverso daquele em que se verá o leitor que passar despercebido pelas referências e paródias.

Neste ponto, observamos aplicar-se o conceito de leitor-modelo, uma vez que o aparato de escolhas estruturais recai sobre o autor-modelo, que vislumbra um certo tipo de leitor que será capaz de acompanhar-lhe o encalço de experimentos. $\mathrm{O}$ controle do autor sobre o leitor cria um paradoxo que desestabiliza a segurança deste diante de uma obra ficcional. $\mathrm{O}$ autor-modelo decreta seu personagem como um autor, que é um escritor de profissão. Mas seu leitor-modelo precisa saber que isso não passa de ficção, do contrário, autor tão bufão quanto Tristram, - que constantemente afronta o leitor, realizando imensas e excêntricas digressões, colando textos em outras línguas e tantas outras dificuldades para acompanhar o fio narrativo - não poderá ser levado a sério. Um dos recursos para afirmar Tristram como autor encontra-se numa nota explicativa que diz: "O autor se engana duplamente aqui [...] Mr Tristram Shandy terá sido levado a tal equívoco, ou por ver o nome Lithopaedus recentemente, num catálogo de autores ilustres feito pelo Dr.----, ou por confundir [...]" (STERNE, 1984, p. 173). A nota consiste numa intromissão do autor-modelo, que rompe com os limites ficcionais, descrevendo ações (representadas pelos verbos "ver" e "confundir") que levaram Tristram a um equívoco enquanto escritor.

O jogo com a realidade e a ficção explora outros níveis, como quando o narrador se dirige aos críticos da revista que haviam julgado Sterne após a publicação de seus sermões religiosos sob o pseudônimo de um bufão: " - - Vós, Senhores Resenhadores da Monthly Review!-Como pudestes cortar e retalhar assim o meu gibão?” (STERNE, 1984, p. 185). Nesse caso, Tristram se refere a receptores que fazem parte da realidade do autor real, além de se referir a discursos que foram emitidos repreendendo os sacrilégios de Sterne.

Nós, leitores reais de Tristram Shandy, poderíamos eleger como representante qualquer um dos tipos de leitores que estão implícitos e ficcionalizados na obra de Sterne. Mas o leitor-modelo, aquele "tipo ideal que o texto não só prevê como colaborador, mas ainda procura criar" (ECO, 1994, p. 15), deve entender a ironia e a sátira presente na obra, acerca das múltiplas formas de se "ler errado", e divertir-se com isso, pois o narratário, ali, é tão bufão quanto o próprio narrador. Para Genette (1930, p. 258), "nós, leitores, não podemos nos identificar mais com esses narratários fictícios do que esses narradores intradiegéticos [como Tristram] se nos podem dirigir, ou, sequer, supor a nossa existência”. Sendo assim, ao dialogar com os resenhadores de uma revista real, estes se tornam narratários, e não representantes do leitor real.

Para Umberto Eco (1994, p. 12), todo texto deixará lacunas que exigirão do leitor escolhas de interpretação, levando-o a adentrar um bosque onde, ainda que possua "[...] trilhas bem definidas, todos podem traçar sua própria trilha, decidindo ir para a esquerda ou para a direita de determinada árvore e, a cada árvore que encontrar, optando por esta ou aquela direção". Não se trata, porém, de uma liberdade com a qual o narratário possa contar, pois está preso às coordenadas do 
narrador. Quando Tristram autoriza seu narratário a ser livre: "a pena para quem salte um capítulo [conforme solicita o narrador] é não compreender todo o resto" (ROUANET, 2007, p. 57).

\section{Considerações finais}

Tristram Shandy é um romance que experimenta novas formas de verdadeiramente representar a individualidade. Ao apresentar sua angústia em busca de melhor abordar o tempo da ação de uma personagem em equivalência ao tempo que se leva para se ler sobre tal, reconhece tratar-se de uma tarefa impossível, pois o fator tempo é soberano. Ainda assim, não tem pressa, e quer que o leitor desfrute do mesmo sabor que ele experimenta em uma narrativa traçada fio a fio, despertando a consciência para a efemeridade do tempo'.

$\mathrm{O}$ ato da leitura é um ato de liberdade, e, ainda que sofra inevitáveis controles sobre o imaginário, condicionados pelas diversas camadas da sociedade, a fruição jamais será unilateral. Posto que a obra de arte é aberta, é "passível de mil interpretações diferentes, sem que isso redunde em alteração de sua irreprodutível singularidade. Cada fruição é, assim, uma interpretação e uma execução, pois em cada fruição a obra revive dentro de uma perspectiva original" (ECO, 2001, p. 40).

Ars longa e Vita brevis, portanto. Tristram reconhece que sua luta contra o tempo é vã, pois a vida não espera e sobre ela o tempo é soberano. Sua escrita precisa ir adiante, mas não descarta o seu método digressivo, que acredita resultar em maior matéria de significação que aguçará a imaginação do leitor:

- - Meu método é sempre o de assinalar, para o curioso, diferentes cursos de investigação, de remontar às fontes primeiras dos acontecimentos que narro;-não com um pedante ponteiro de Mestre-Escola, nem à maneira resoluta de Tácito, que acaba por lograr-se a si mesmo e ao leitor;-mas com a solícita humildade de um coração devotado tão-só a assistir os indagadores; para eles escrevo,-e por eles serei lido-—se é de supor que uma leitura como esta possa durar tanto que alcance o fim do mundo. (STERNE, 1984, p. 101).

Nesse bosque labiríntico, seu amigo leitor, que lhe acompanha na tessitura, precisa fazer escolhas e decidir por manter ou quebrar o pacto com o narrador. Talvez não seja esse o dilema que nós, leitores-empíricos, tenhamos de lidar. O leitor, ficcionalizado em Tristram Shandy, ajuda o leitor-empírico a refletir sobre as engrenagens narrativas. O narratário, portanto, não consiste em uma forma de controle sobre os leitores reais, nem servem a este como identificação na obra. São, contudo, mecanismos que evidenciam práticas de leitura e simbolizam uma realidade social, expondo uma forma bem humorada de questionar as convenções por meio da arte. O narratário não é o cárcere do leitor-empírico, pois este ainda dispõe de liberdades não previstas pela obra. Não está, porém, livre do controle do autor. Mas, isso, a ambiguidade da obra trata de disfarçar. 
Notas

1. A tradução em português adotou o termo leitor virtual, que equivale a leitor implícito utilizado neste artigo, pois é inclusive o termo utilizado na tradução para o inglês "implied reader": Cf.: GENETTE, Gérard. Narrative Discourse: an essay in method. New York: Cornell University, 1980, p. 259.

2. No original: "[...] witness to the impossibility of perfect communication in language, which may be why no early reader is known to have taken up Tristram's challenge in any surviving copy".

3. Enquanto sua mãe está em processo de parto no andar de cima da casa, Tristram narra os fatos que estavam ocorrendo no andar de baixo.

4. Esse aspecto da obra foi muito bem retratado na adaptação cinematográfica "Tristram Shandy: A Cock and Bull Story (2005), por Michael Winterbottom.

5. Na edição em inglês, o gênero é dado pela palavra Madam, e em português utilizou-se apenas "sentada" para a definição do gênero do narratário. Cf.: STERNE, 2005, p. 460.

6. No inglês, aparece até mesmo a palavra "dumb" e "dum", que significam "pateta" "abobalhado": Fa-ra diddle di / and a fa-ri diddle d / and a high-dum-dye-dum / fiddle---dumb - c. (STERNE, 2005, p. 460).

7. Na edição em língua inglesa: For he is to be drawn into a dialogue in which the narrator, the author and the characters are already mixed, if not mixed up. The reader's participation, however, must be such that he will be prevented from removing the plurivocity by means of his own projections. The narrator has been at pains to produce openness through his interruptions, and so it is essential that the reader should not be allowed to impose his own patterns, thereby closing up what has been opened. (ISER, 2008, p. 63)

8. Sterne foi pároco de um igreja anglicana, e depois de abdicar de seus serviços cristãos publicou seus sermões que tinham cunho filosófico e literário, intitulados The sermons of Mr. Yorick, em referência à personagem de Hamlet.

9. É válido destacar uma das líricas menções ao tempo, com as quais Sterne nos presenteia: "o tempo passa rápido demais; cada letra que traço fala-me da rapidez com que a Vida acompanha minha pena; seus dias e suas horas, mais preciosas, minha querida Jenny! do que os rubis à volta do teu pescoço, estão voando por sobre as nossas cabeças, quais leves nuvens num dia de vento, para nunca mais voltar [...]" (STERNE, 1984, p. 587-8)

\section{Referências}

BAKHTIN, Mikhail. Marxismo e filosofia da linguagem: problemas fundamentais do método sociológico da linguagem. Tradução: Michel Lahud et. al. 12a ed. São Paulo: Hucitec, 2006.

BLANCHOT, Maurice. O livro por vir. Tradução: Leyla Perrone-Moisés. 3. ed. São Paulo: Martins Fontes, 2018.

BOOTH, Wayne C. Tristram Shandy and its precursors: The Self-conscious Narrator. 1950. Tese de Doutorado (Ph.D. in English Language Literature) - Universidade de Chicago. 1950.

BOOTH, Wayne C. The self-conscious narrator in comic fiction before Tristram Shandy. Publications of the Modern Language Association (PMLA), v. 67, p. 163-85. 1952.

CEIA, Carlos. Tristram Shandy e Viagens na minha terra: paradigmas da metaficção. Scripta, Belo Horizonte, v. 3, n. 5, p. 19-33, 2. sem. 1999. 
DEJEAN, Joan. Antigos contra modernos: as guerras culturais e a construção de um fin de siècle. Tradução: Zaida Maldonado. Rio de Janeiro: Civilização Brasileira, 2005.

DE VOODGE, Peter. Sterne and visual culture. In: KEYMER, Thomas (Ed.). The Cambridge companion to Laurence Sterne. New York: Cambridge University Press, 2009.

ECO, Umberto. Seis passeios pelos bosques da ficção. Tradução: Hildegard Feist. São Paulo: Companhia das Letras, 1994.

Obra aberta. In: Obra aberta: forma e indeterminação nas poéticas contemporâneas. 8. ed. Tradução: Giovanni Cutolo. São Paulo: Perspectiva, 2001.

Interpretação e Superinterpretação. Tradução: M F. 2. ed. São Paulo: Martins Fontes, 2005.

FANNING, Christopher. On Sterne's page: spatial layout, spatial form, and social spaces in Tristram Shandy. Eighteenth-Century Fiction, v. 10, n.4, p. 429-450, July.1998.

GAMA-KHALIL, Marisa Martins. Os espaços do leitor ficcionalizado: nas teias dialógicas de Henry Fielding e Laurence Sterne. Itinerários, Araraquara, n.37, p.141-154, jul-dez. 2013.

GENETTE, Gérard. Discurso da narrativa. Tradução: Fernando Cabral Martins. Lisboa: 1930.

Narrative Discourse: an essay in method. Trad. Jane E. Lewin. New York: Cornell University, 1980.

HUTCHEON, Linda. Uma teoria da paródia: ensinamentos das formas de arte do século XX. Tradução: Teresa Louro Pérez. Lisboa: Edições 70, 1985.

ISER, Wolfgang. Laurence Sterne: Tristram Shandy. New York: Cambridge University, 2008.

LAJOLO, Marisa. ZILBERMAN, Regina. A formação da leitura no Brasil. São Paulo: Ática, 1998.

LIMA, Luiz Costa. O controle do imaginário e a afirmação do romance: Dom Quixote, As relações perigosas, Moll Flanders, Tristram Shandy. São Paulo: Companhia das Letras, 2009.

NEW, Melvyn. Sterne and the narrative of determinateness. Eighteenth-Century Fiction, v.4, n.4, p. 315-330, July 1992. Disponível em: https://doi.org/10.1353/ ecf.1992.0038. Acesso em 19 nov. 2020.

NOGUEIRA, Nícea Helena de Almeida. Laurence Sterne e Machado de Assis: a tradição da sátira menipéia. Rio de Janeiro: Galo Branco, 2004.

ROUANET, Sergio Paulo. Riso e melancolia: a forma shandiana em Sterne, Diderot, Xavier de Maistre, Almeida Garrett e Machado de Assis. São Paulo: Companhia das Letras, 2007.

STERNE, Laurence. A vida e as opiniões do cavalheiro Tristram Shandy. Tradução: José Paulo Paes. Rio de Janeiro: Nova Fronteira, 1984.

VASCONCELOS, Sandra Gardini Teixeira. A formação do romance inglês: ensaios teóricos. São Paulo: Fapesp, 2007.

WOOLF, Virginia. O leitor comum. Tradução: Luciana Viégas. Rio de Janeiro: Grafia, 2007. 